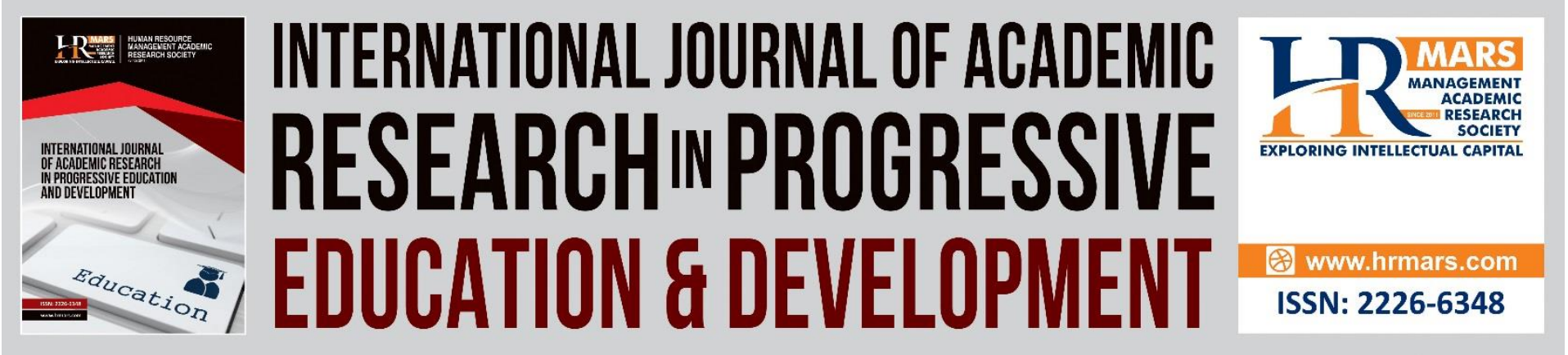

\title{
The Languages of the Arabs and Their Relationship to The Qiraat in The Interpretation of Ibn Ajiba
}

Mohamed Fathy Mohamed Abdelgelil, Yaser Mohammed Awadh Alshaheri, Mukhamad Hadi Musolin Subagio, Ahmad Fauzi Hassan, Ammar Kamal Ibrahim Othman, Najmiah Omar

To Link this Article: http://dx.doi.org/10.6007/IJARPED/v10-i3/11186

DOI:10.6007/IJARPED/v10-i3/11186

Received: 08 July 2021, Revised: 11 August 2021, Accepted: 25 August 2021

Published Online: 23 September 2021

In-Text Citation: (Abdelgelil et al., 2021)

To Cite this Article: Abdelgelil, M. F. M., Alshaheri, Y. M. A., Subagio, M. H. M., Hassan, A. F., Othman, A. K. I., \& Omar, N. (2021). The Languages of the Arabs and Their Relationship to The Qiraat in The Interpretation of Ibn Ajiba. International Journal of Academic Research in Business and Social Sciences, 11(9), 759-765.

Copyright: (C) 2021 The Author(s)

Published by Human Resource Management Academic Research Society (www.hrmars.com)

This article is published under the Creative Commons Attribution (CC BY 4.0) license. Anyone may reproduce, distribute, translate and create derivative works of this article (for both commercial and non-commercial purposes), subject to full attribution to the original publication and authors. The full terms of this license may be seen at: http://creativecommons.org/licences/by/4.0/legalcode

Vol. 10(3) 2021, Pg. 759 - 765

http://hrmars.com/index.php/pages/detail/IJARPED

JOURNAL HOMEPAGE

Full Terms \& Conditions of access and use can be found at http://hrmars.com/index.php/pages/detail/publication-ethics 


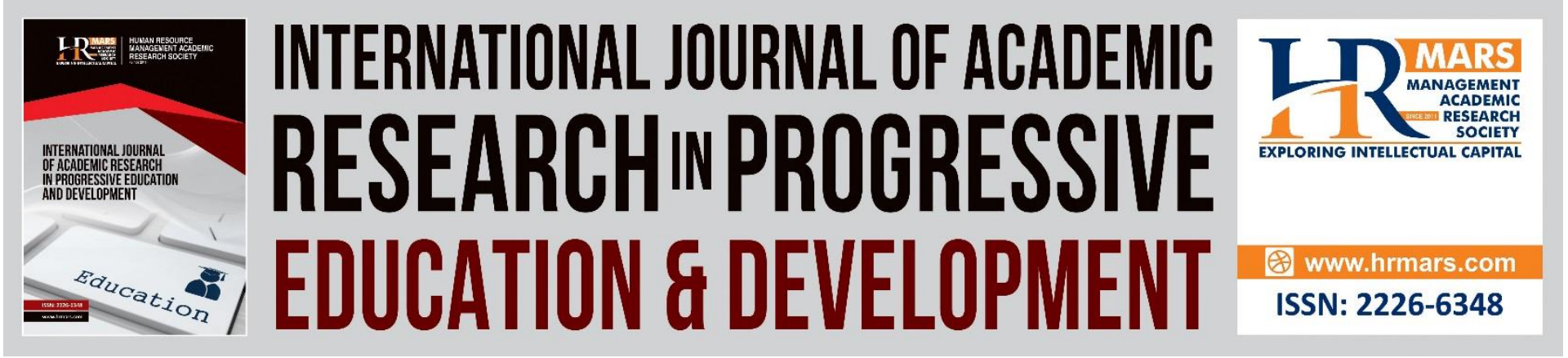

\title{
The Languages of the Arabs and Their Relationship to The Qiraat in The Interpretation of Ibn Ajiba
}

\author{
${ }^{1}$ Mohamed Fathy Mohamed Abdelgelil, ${ }^{1}$ Yaser Mohammed \\ Awadh Alshaheri, ${ }^{2}$ Mukhamad Hadi Musolin Subagio, ${ }^{1}$ Ahmad \\ Fauzi Hassan, ${ }^{1}$ Ammar Kamal Ibrahim Othman, ${ }^{1}$ Najmiah \\ Omar \\ ${ }^{1}$ Faculty of Islamic Contemporary Studies (FKI), Sultan Zainal Abidin University (UniSZA), \\ MALAYSIA, ${ }^{2}$ Sultan Abdul Halim Mu'adzam Shah International Islamic University, \\ (UniSHAMS), Malaysia. \\ Email: yaseralshahiri@gmail.com
}

\begin{abstract}
The interpretation of Imam Ibn Ajiba is considered one of the most important references that took care of directing the Qur'anic Qiraat that were stated by a number of Arab tribes. The dispute has intensified among the scholars regarding the meaning of the seven modes contained in the consecutive hadith, and in directing those dialects in which the Qur'an was revealed. Ibn Ajiba had a different saying far from what those contradictory statements went to. Therefore, this study aimed to clarify the relationship of the Arabic dialects to the seven modes and the extent of their impact on the Qur'anic Qiraat, and to clarify the statement of Ibn Ajiba regarding the meaning of the seven modes contained in the hadith. The method followed is: The qualitative method: Focusing on collecting information and then discussing it through description and analysis to reach specific results. The study concluded that Ibn Ajiba took care in his interpretation of the guidance of the various Arabic dialects that were mentioned in the Holy Qur'an and their counterparts, which are true in the dialects of the Arabs. And that the Arabic languages, with their various dialects, had a prominent role in the diversity and difference of Qur'anic Qiraat, and Ibn Ajiba's interest in mentioning and directing them in his interpretation of Al-Bahr Al-Madid was evident. He proved that the difference in the Qur'anic Qiraat is a matter of rhetorical beauty and not a difference of contradiction. Ibn Ajiba also sees that the hadith of the seven modes is enigmatic whose meaning is not understood, similar to the obscure in the Qur'an and the hadith, which is what the researcher favored; Because the large number of differences in the meaning of a thing increases its ambiguity and the lack of clarity of its purpose, and Allah knows best.

Keywords: Dialects of the Arabs, Relationship, Qiraat, Interpretation, Ibn Ajiba.
\end{abstract}


DEVELOPMENT

Vol. 10, No. 3, 2021, E-ISSN: 2226-6348 @ 2021 HRMARS

\section{Introduction}

Many of the people of the art of Qiraat worked hard to prove in their interpretations all the Qiraat with what was mentioned in the words of the Arabs, because the Qur'an came in a clear Arabic tongue; Because reading is a followed way, and not everyone who has a tradition of Qiraat has the right to come up with a reading or read what is authentic from the words of the Arabs, so some grammarians objected to some of the Qiraat received, to the extent that some of them denied some of what was consecutive from them, and this is a disaster in the religion.

\section{Preface}

Imam Ibn Ajiba took care in his interpretation of Al-Bahr Al-Madid in the interpretation of the Glorious Qur'an with directing the various Arabic dialects that were mentioned in the Holy Qur'an and their counterparts from what is true in the Arab dialects (Abdelgelil et al., 2019; Abdelgelil et al., 2018), which in turn came with many meanings that may agree in some places and may differ in others. This difference was a difference of diversity and not a difference of contradiction, and Imam Ibn Ajiba proved that in many verses from them, and this guidance came from one place to another from that (Abdelgelil et al., 2021; Abdelgelil et al., 2020).

\section{Imam Ibn Ajiba and the seven modes}

The difference in narrations in the Noble Qur'an is attributed to the hadith of the seven modes, which reached the level of succession, but scholars differed in the interpretation of the meaning of the seven modes. Imam Ibn Ajiba has an opinion on that as well, and he reported the most correct of what was said about that, so he said:

1. What is meant by the seven modes are seven of the dialects of the Arabs, namely Quraysh, Hudhayl, Thaqif, Hawazin, Kinana, Tamim, and Yemen, and in this he follows what Imam Abu Ubaid reported, which is the saying of Abu Ubaidah, Tha lab, al-Azhari, and authenticated by al-Bayhaqi and Ibn Atiyah (Ibn Ajiba, 2013; Ibn Ajiba, 1999).

2. What is meant is seven aspects of meanings that agree with different words, and they are as you say, come, come, hurry, and this is what Ibn Wahb and Suleiman bin Ubaidah said.

As for the opinion of Imam Ibn Ajiba on that, he says: The chosen one is that this hadith is a enigmatic, whose meaning is unknown, similar to the obscure in the Qur'an and the hadith (Ibn Ajiba, 2013, 17).

\section{A pause with the opinion of Imam Ibn Ajiba}

Imam Ibn Ajiba chose this saying due to what he witnessed of the many differences in the meaning of the seven modes, and it is known that the greater the difference in the meaning of a thing, the more this disagreement increases the ambiguity in it and the lack of clarity of its intended purpose. All the opinions mentioned by the precedents and others regarding the meaning of the seven modes, we find that there is a correction to them, among them we mention the following:

1. What was mentioned as a dialect dispute between the Arabs?

We find that the disagreement mentioned in the hadith was between two men of Quraysh who spoke the same dialect, so how could they differ in their dialect.

The second meaning in the meaning of the seven modes is what Imam Ibn Al-Jazari mentioned 
DEVELOPMENT

Vol. 10, No. 3, 2021, E-ISSN: 2226-6348 @ 2021 HRMARS

2. Which is that they are two types of difference.

This saying is responded by clarifying that Imam Ibn Al-Jazari, may Allah have mercy on him, looked in the incoming Qiraat and came up with this division based on what was reported from the Qiraat, but if we look at this division and at the wisdom for which the seven modes came, it becomes clear that in some types the wisdom of ease is not fulfilled, for example: The difference in anastrophe, gender, or singularity, duality and plurality, all of these types do not have any difficulty and the wisdom of facilitation cannot be descended into them. The opinion of Imam Ibn Ajiba, may Allah have mercy on him, in this is a kind of research, in order not to be certain about something in which the disagreement has increased and intensified. The way out is that it is said that the seven modes are known only by Allah, Glory be to Him, (Ibn Ajiba, 2013, 16).

\section{Dialects proven in directing}

One of the most correct statements in the interpretation of the seven modes is that what is meant by them are the Arabic dialects, and some of them counted seven of them. And they cited a lot of evidences for that which do not need to be mentioned in this regard, but it is sufficient that Ibn Ajiba has made it clear that many of them was mentioned in the Qiraat, whether consecutive or odd, and after directing the reading, he shows who uses this dialect and from these dialects that he proved is:

\section{Hijaz Dialect}

The people of Hijaz, are the people of Mecca and Medina, and of the words that are attributed to them, is what he mentioned when the Most High said: "But how for them will be (the taking [of faith]) "التناوش" from a place far away?" Whoever reads it with the waw, then believes that it is an action noun for the verb (نوشاً ينوش ناش), meaning take which is a Hijazi dialect, and from it is: People fought in war: If they get close, and who reads it with the hamz pointed out that it is the action noun of (تناءش), meaning slow down (Ibn Ajiba, $1999,4 / 509)$.

\section{Quraysh Dialect}

The dialect of Quraysh is the first dialect in which the Noble Qur'an was revealed, and was even the dialect to which the scribes of the Noble Qur'an refer to when there is a difference in writing any word of the Qur'an, because our Uthman bin Affan ordered them to write the Qur'an according to the letters that were proven in the last presentation, but he told them if you disagreed on something, see how it is written in the dialect of Quraysh, because the Qur'an was revealed at the beginning of the revelation in the dialect of Quraysh, and from the positions that Ibn Ajiba referred to as a use of the dialect of Quraysh is what is mentioned when the Almighty said: "...so ask the Children of Israel [about] when he came to them and Pharaoh said to him, "Indeed I think, O Moses, that you are affected by magic." (Al Esraa 101), He said: We told Moses: Ask for the Children of Israel from Pharaoh, i.e.: Ask them from him to send them with you, or ask the children of Israel to support you and be with you. This is supported by: The reading of the Messenger of Allah, may Allah's prayers and peace be upon him, as "سل "is based on the past tense without a hamz, which is the dialect of Quraysh" (Ibn Ajiba, 1999, 3/239). 
DEVELOPMENT

Vol. 10, No. 3, 2021, E-ISSN: 2226-6348 @ 2021 HRMARS

\section{Tamim and Najd Dialect}

Among the well-known and famous dialects are these two Arabic dialects, and in the Qur'an many places with the dialect of Tamim were present, and we find from it what Ibn Ajiba mentioned when Allah Almighty says: "...He will exterminate you with a punishment; and he has failed who invents [such falsehood]." (Surat Taha, 61), he said in its interpretation: The verb was read as quadrilateral and triple, it is said: (سحت وأسحت), as the triple is: dialect of people of Hejaz and the quadrilateral is: the dialect of Bani Tamim and Najd" (Ibn Ajiba, 1999, 3/399).

\section{Hawazen Dialect}

He referred to the dialect of this tribe when Allah Almighty said: "...Then have those who believed not accepted that ..." (Surat Ar-Ra'd, 31), (أفلم يَيْاََسِ) means: Those who believe know that guidance is in the hands of Allah, and His will, so if He wanted He would guide all people.

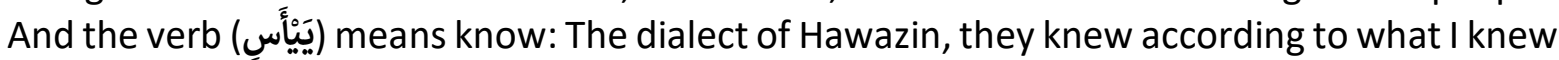
of them that Allah does not guide those who go astray" (Ibn Ajiba, 1999, 3/29).

\section{Referring to the Dialect of Quraish when there is a Disagreement}

It was also reported that Othman bin Affan, may Allah be pleased with him, that he commanded the scribes of the Qur'an to refer to the dialect of Quraish in the event of disagreement, because the Qur'an was revealed in the beginning with their dialect, and it was final arbiter. Likewise, those after them also knew that the basic principle is that when they differ, they return to what the people of Mecca are upon, and this was mentioned by Ibn Ajiba when Allah Almighty says: "...he found it [as if] setting in a spring of dark mud..." (Surat Al-Kahf, 86).

The reading came in two ways, and each of them has a meaning, but it is permissible to bring the two meanings as well He found it, i.e.: the sun, setting in a spring of dark mud, i.e.: of a dark mud, this is the meaning when reading the verse with the word (حمئة), but on another reading it came: (حامية) i.e.: intensely hot, he mentioned the disagreement about Muawiyah, may Allah be pleased with him, when he recited it as (حامية), and Ibn Abbas was with him. Ibn Abbas, may Allah be pleased with him, said to him: (حمئة), Muawiyah said to Abdullah bin Amr bin Al-Aas: How do you read? He said: As the Commander of the believers reads" (Ibn Ajiba, 1999, 3:302).

He wanted to know the meaning that came through the question to the People of the Book, how was it revealed to them, so he turned to Ka'ab al-Ahbar, and asked him how do you find the sun setting? He said: in water and mud, that's how we find it in the Torah, and he agreed with the saying of Ibn Abbas, may Allah be pleased with him, and when he heard that, he returned to the reading of Ibn Abbas, but both Qiraat are frequent.

\section{Conclusion}

In this study, the researcher reached a set of results, which are as follows:

1. The Arabic languages, with their various dialects, had a prominent role in the diversity and difference of Qur'anic Qiraat, Ibn Ajiba's interest in its reference and guidance was evident in his interpretation of Al-Bahr Al-Madid and its counterparts, which is true in the dialects of the Arabs. 
2. Imam Ibn Ajiba proved in his interpretation that the difference in the Qur'anic Qiraat arising from what is authentic from the dialects of the Arabs is a matter of rhetorical beauty and not a difference of contradiction.

3. The scholars differed regarding the meaning of the seven modes in the consecutive hadith into many meanings, but Ibn Ajiba believes that "this hadith is one of the enegmatic ones whose meaning is not known similar to the obsecure in Qur'an and the hadith"; In view of what he saw of the many differences in the meaning of the seven modes. It is known that the greater the difference in the meaning of a thing, the more this disagreement increases the ambiguity in it and the lack of clarity of its intended purpose. All the opinions mentioned by precedents and others regarding the meaning of the seven modes, we find that there is a correction to them. Each saying they mentioned, there is a saying that counters it. Therefore, Ibn Ajiba's opinion, may Allah have mercy on him, has a kind of research, so as to avoid being assertive about something in which the dispute was intense and abounding, that to be said that the seven modes are from what Allah, the Exalted, the Most High, only knows.

\section{Acknowledgement}

Special thanks go to the Research Management, Innovation and Commercialization Centre (CREIM), Sultan Zainal Abidin University (UniSZA), MALAYSIA.

\section{References}

Al-Quran Al-Karim.

Abbas, F. (1997). Itqan al-Burhan Fi Ulum al-Qur'an, Amman: Dar al-Furqan.

Abdelgelil, M. F. M. (2020). Grammarians' Critique of Qur'anic Qira'at. International Journal of Academic Research in Business and Social Sciences, 10(11), 1225-1231.

Abdelgelil, M. F. M. (2020). Solving the Quranic Issues with Quranic Qira'at, International Journal of Academic Research in Business and Social Sciences, 10(12), 36-42.

Abdelgelil, M. F. M., Al-Janayni, M. U., Baru, R., Hamzah, M. S., Razali, M. A. T. M., \& Ismail, F. Z. (2018). Tawjih Al-Qira'at Based on Inscription, Language, and Unusual Modes of Recitation According to Ibn Zanjalah. International Journal of Academic Research in Business and Social Sciences, 8(10), 362-370.

Abdelgelil, M. F. M., Daud, N. B., Omar, N. B., Ismail, F. Z. B., \& Wahab, A. H. B. A. (2018). Taujeeh Al-Qira'at Using Qur'an, Hadith and Poetry according to Ibn Zanjalah. International Journal of Academic Research in Business and Social Sciences, 8(10), 371379.

Abdelgelil, M. F. M., Hasan, A. F., Yusoh, F, El khayat, M. H. M., Razali, M. A., Ismail, F. Z., \& Ab Rashid, R. (2021). Correlation Between Irregular Qiraat And Arabic Linguistics In The Quranic Tafseer Book By Al-Razi. International Journal of Academic Research in Business and Social Sciences, 11(7), 1632-1639.

Abdelgelil, M. F. M., Hasan, A. F., Yusoh, F., Ismail, F. Z., Ab Rashid, R., Ab Aziz, N. S., Hassan, A (2021). The Impact of Irregular Qiraat on Arabic Semantics and Dialects. International Journal of Academic Research in Business and Social Sciences, 11(7), 1672-1676.

Abdelgelil, M. F. M., Hasan. A. F., Yusoh, F., El khayat, M. H. M., Razali, M. A., Hassan, A., Ab Aziz, N. S. (2021). Arabic Syntactic Rules with Reference to Quranic Qurra. International Journal of Academic Research in Business and Social Sciences, 11(7), 1707-1711. 
Abdelgelil, M. F. M., Musolin, M. H., Serour, R. O. H., Abdullah, M. S., \& Noor, M. N. M. (2018). Law and Moral Values in the Holy Quran. International Journal of Academic Research in Business and Social Sciences, 8(11), 445-451.

Abdelgelil, M. F. M., Osman, M. F. M. A., Serour, R. O. H., Subagio, M. H. M., Othman, A. K. I., \& Hassan, A. F. (2021). The History of the Qur'anic Enigma and the Impact of Interpretation in Directing it. International Journal of Academic Research in Progressive Education and Development, 10(3), 412-418.

Abdelgelil, M. F. M., Othman, A. K. I., Serour, R. O. H., Osman, M. F. M. A., \& Hassan, A. F. (2021). Ibn Qutayba's Response to the Slanderers who Claim Grammatical Mistake in the Qur'an. International Journal of Academic Research in Progressive Education and Development, 10(3), 419-426.

Abdelgelil, M. F. M., Othman, A. K. I., Subagio, M. H. M., Serour, R. O. H., Hassan, A. F., \& Osman, M. F. M. A. (2021). Directing the Enigma of Quranic Words According to Ibn Qutaybah and Al-Far. International Journal of Academic Research in Progressive Education and Development, 10(3), 427-434.

Abdelgelil, M. F. M., Razali, M. A., Hassan, A., Hasan, A. F., Idris, M. F. H., \& Masoud. (2020). A.S,Quranic Inimitability in Quranic Qiraat, International Journal of Management, 11(10), pp. 117-121.

AL-Azhari, M. B. A. (1991). Ma'ani Alqira'at Lila'azhari. Riyadh: King Saud University, College of Arts, Research Center.

AL-zarqani, M. A. L. (2020). Manahil AE'rfan Fi Ulum Alqura'an. Bairot: Dar Al-kitab Al-a'arabi. 